\title{
Chemical Composition of Major Cassava Varieties in Uganda, Targeted for Industrialisation
}

\author{
John Manano ${ }^{1}$, Patrick Ogwok ${ }^{1} \&$ George William Byarugaba-Bazirake ${ }^{1}$ \\ ${ }^{1}$ Department of Food Technology, Kyambogo University, P.O. Box 1, Kyambogo, Uganda \\ Corresponding author: John Manano. Department of Food Technology, Kyambogo University, P.O. Box 1, \\ Kyambogo, Uganda. E-mail: jmanano@yahoo.com
}

Received: March 7, 2017

Accepted: April 11, $2017 \quad$ Online Published: November 21, 2017

doi:10.5539/jfr.v7n1p1

URL: https://doi.org/10.5539/jfr.v7n1p1

\begin{abstract}
Uganda is one of the major cassava producing countries in the world. Currently, utilization of cassava is limited to semi-processed products through the informal sector. Cassava has technological potential as a raw material for agro-industrial products, such as flours for baked products, animal feeds and starch. The aim of this study was to investigate the chemical composition of five major cassava varieties grown in Nebbi distict (Uganda), to assess their potential as industrial raw materials. Analysis of the chemical composition of local (Nyamatia and Nyarukeca) and improved (NASE 3, NASE 14, and NASE 19) cassava varieties was carried out using standard methods. Results showed significant $(\mathrm{p}<0.05)$ differences between the varieties indicating high levels of starch, calcium, magnesium, cyanonenic glucosides and phytates. The cassava varieties contain low levels of protein, lipids and minerals with respect to recommended daily intake of these nutrients. Moisture contents ranged from 5.43 for Nyamatia to 10.87 for NASE 19; ash from 1.05 for Nyamatia to 2.39 for NASE 14; crude fiber from 1.06 for Nyamatia to 1.18 for NASE 19; crude protein from 0.74 for Nyarukeca to 1.51 for NASE 14; crude lipid from 0.39 for Nyamatia to 0.63 for NASE 19; and starch contents from 66.72 for NASE 19 to 84.42 for NASE 3 . The mineral contents (mg/kg): calcium ranged from 13.15 for Nyamatia to 16.56 for NASE 3; iron ranged from 0.002 for Nyarukeca to 0.01 for NASE 19; zinc ranged from 0.56 for Nyamatia to 0.87 for NASE 3; magnesium ranged from 3.58 for NASE 19 to 3.88 for Nyarukeca; and copper ranged from 0.002 for Nyamatia to 0.14 for NASE 3. The contents of anti-nutrients $(\mathrm{mg} / \mathrm{kg}$ ): cyanogenic glucosides ranged from 30 in NASE 3 and NASE 19 to 800 in Nyamatia; phytates ranged from 661.33 in Nyarukeca to 984.64 in NASE 3; oxalates ranged from 90.6 in Nyarukeca to 227.8 in NASE 3; and tannin ranged from 0.18 in Nyarukeca to 0.33 in NASE 3. Based on the chemical composition results, all the cassava varieties studied contain higher levels of cyanogenic glucosides than recommended by Ugandan and East African Standards, making them unsafe for direct utilization as food and food raw materials for industries at levels beyond $30 \%$ in food formulations. The high starch levels in all the cassava varieties make them valuable raw materials for starch and starch-related industries.
\end{abstract}

Keywords: anti-nutrients, cassava varieties, chemical composition, Uganda

\section{Introduction}

Cassava (Manihot esculenta Crantz) is a perennial woody shrub with an edible root, which is widely grown and consumed in tropical and subtropical areas of the world to stave off famine. Uganda is one of the major cassava producers in the world (National Cassava Policy (NCP), 2013). Of the food crops cassava has for a long time been the food security base of the country and has been one of the most important crops in Uganda. However, cassava in Uganda is still a staple food in homes as famine food (security) reserve unlike in Nigeria and Ghana where it is a cash crop and an industrial raw material used in the formulation of various value-added products. Cassava production is in substantial volumes with exceptional production in Northern and Eastern regions of the country. The districts of Lira, Apac, Gulu, Arua, Nebbi, Soroti, Kumi, Tororo, Pallisa, Iganga, and Kamuli are major cassava producing areas (Uganda Census of Agriculture (UCA), 2008/2009; Cassava: Adding Value for Africa (C:AVA), 2007). Currently, cassava is the second most important food crop in Uganda after matooke and its production is estimated at 5.3 million metric tonnes per annum worth about US\$5.5 billion (FAOSTAT, 2011). Utilization of cassava is however, limited to semi-processed products through the informal sector and not on industrial scale. The crop has technological potential as a raw material for agro-industrial products, such as flours in baked products, animal feeds and starch (Graffham et al., 2000). Hence, cassava could be exploited to 
avert food insecurity situation in poor communities and as well contribute to economic development in the country (Sanni et al., 2005).

Cassava is used in many industries including in bakery and confectionaries, brewing, pharmaceuticals, distilleries and packaging industries. Cassava value chain in Nigeria has tremendously contributed to agro-processing industry (Anyiro and Onyemachi, 2014; Ndubueze-Ogaraku and Edema, 2015). Recent developments in Uganda have involved cassava flour in beer brewing at Uganda Breweries Ltd., an innovation beer product known as "engule" that is desired on market nationally, and another trial is underway at Nile Breweries Ltd for another brand of beer. One of the cassava conventional products of economic value for farmers as well as various industries is cassava starch. Variations in starch and sugar concentrations in different cassava varieties would influence to varying levels their organoleptic properties, functionality and physico-chemical properties during their applications in food and industrial processing. Characterization of cassava varieties for their starch and other chemical components would be beneficial in selecting cassava varieties for specific food formulation, processing and ultimately industrial applications. National and regional regulatory authorities have put requirements on the quality of cassava products (Uganda Standards, US 347:2007 for cassava flour; US 597: 2007 for cassava starch). Different industry subsectors have their specific requirements for physical and chemical requirements on cassava flour or cassava starch. Industries in Uganda import starches, dextrin and cassava substitutes from South Africa, Kenya, and Tanzania. Starches largely constitute those from maize and wheat. The importation of starch, dextrin, and cold-setting adhesives leads to loss of large amounts of foreign currency, and to increased unemployment. The extraction of starch from locally grown raw materials will save the country substantial amount of foreign exchange, provide cheap material for research (starch modification), and improve on the knowledge about cassava and its products and eventually create jobs for Ugandans mainly in the starch processing and brewing industries.

Hundreds of cassava varieties are grown in various regions of Uganda. The improved varieties include the NASE family (NASE 1 - NASE 19), NARO CAS 1 and NARO CAS 2; Migyeera, Bukalasa 8, Bukalasa II, and the local varieties include Bao, Okonyoladak, Icilicil, Arawkirra, Tyeno, Oturolak Ayita, Ebwanatereka, Empologoma, Bintiminsi, Serere, Sukari, Kiwoko, , Kulanabwana, Ongada, Akena, Ochide, Angaraba, Malukwa, Nyaraboke, Kakwale, Bamunanika (Ameny, 1990; Nuwamanya et al., 2010). Varietal and environmental factors are known to affect cassava root composition (Corbishley and Miller, 1984). The chemical composition of cassava roots also differs depending on cultural practices like pruning, age and maturity of the root at harvest, storage environment, region, and post-harvest practices. All cassava varieties contain the toxic cyanogenic glucosides Linamarin and Lotaustralin at different concentrations of 150 to $300 \mathrm{mg} / \mathrm{kg}$ in peeled root or 300 to $900 \mathrm{mg} / \mathrm{kg}$ of the dry matter (Asiedu, 1989; Aalbersberg et al., 1991; Wheatley et al., 1993; Cardoso et al., 2005). Cyanide content of cassava tends to increase during periods of droughts and or prolonged dry weather due to water stress on the plant (Bokanga et al., 1993; Bokanga, et al., 1994). Splittstoesser and Tunya (1992) reported that cassava grown in wet areas contain relatively lower amount of cyanide than those grown in drier areas. Cyanide levels in cassava affect the extent of its acceptability for commercialization. Cyanogenic glucosides may affect local nutrition and may lead to the incidence of cassava related diseases, such as goiter and spastic paraparesis (konzo). However, postharvest handling like fermentation and drying decreases the cyanide amount to acceptable levels. The starch content of cassava largely influences the functional and physico-chemical properties of food systems. These properties include swelling power, swelling volume, solubility, water binding capacity and pasting properties. Afoakwa et al. (2011) suggested that cassava varieties with high moisture and reducing sugar contents would be suitable for fermentation, and could be successfully used as raw material in ethanol, organic acids, lactic bacteria, biofuel industries and may be in latest brewing innovations like the new beer produced at Uganda Breweries Ltd made from cassava flour. Cassava growers, product formulators and developers as well as consumers should therefore know the composition of different cassava varieties. Other processors of non-food products should be able to choose the right varieties for their processes and hence products.

This work characterized cassava varieties based on proximate compositions, concentrations of selected minerals and anti-nutrients in some local and improved high yielding and cassava mosaic disease (CMD) resistant cassava varieties grown in Uganda.

\section{Methodology}

\subsection{Sample Collection and Sampling}

Cassava roots from three improved varieties, NASE 3, NASE 14, and NASE 19, were purchased from a farmer at Pukweru, Panyango sub-county in Nebbi district (Uganda). Roots from two local varieties, Nyamatia and 
Nyarukeca, were purchased from Gamba village, in Nebbi sub-county, Nebbi district. All the starchy roots were purchased in October, 2016, during the rainy season. The roots were separately washed, weighed and peeled. The peeled roots were sliced using a new grating hand-machine into smaller pieces, dried at $50 \pm 2{ }^{\circ} \mathrm{C}$ for 24 hours in hot-dry air oven and cooled in air at ambient temperatures. The samples were packaged in dry and new polythene bags purchased from Afroplast Ltd., Kampala, and stored at ambient temperature. Cassava samples were ground to powder using mortar and pestle. The analyses were carried out at Uganda Industrial Research Institute, Chemistry Laboratory and Government Analytical Laboratories.

\subsection{Determination of Moisture}

The method described by AOAC (1995) was adopted where weighed fresh samples were dried in an air oven (Memmet, UFE - 600), at $105^{\circ} \mathrm{C}$ to a constant weight. The percentage moisture content was calculated as the difference between the fresh and dry weights.

\subsection{Determination of Ash}

The ash content was determined by the drying method described by AOAC (1995) where weighed sample was heated at $550{ }^{\circ} \mathrm{C}$ for $5 \mathrm{hrs}$ to ensure proper ashing. The percentage ash content was calculated.

\subsection{Determination of Crude Fibre}

The method described by AOAC (1995) was used for determining the crude fibre of cassava. Two grams of cassava flour was boiled in $100 \mathrm{~mL}$ of $0.25 \mathrm{M}$ sulphuric acid solutions under reflux for $30 \mathrm{~min}$. The hot solution was quickly filtered under suction pressure. The residue was thoroughly washed with hot water until it was acid free. The residue was then boiled in $100 \mathrm{~mL}$ of hot $0.3 \mathrm{M}$ sodium hydroxide solution under reflux for $30 \mathrm{~min}$ and filtered quickly under suction. The insoluble residue was washed with hot water until it was base free. It was dried to a constant weight in an oven at $100^{\circ} \mathrm{C}$ for $2 \mathrm{hrs}$, cooled in a desiccator and weighed. The percentage crude fibre content was calculated.

\subsection{Determination of Nitrogen and Crude Protein}

Micro Kjeldahl method (AOAC, 1995) was used. Sample was digested using sulphuric acid and mixed catalyst $\left(96 \% \mathrm{CuSO}_{4}+3.5 \% \mathrm{Na}_{2} \mathrm{SO}_{4} 0.5 \%\right.$ selenium oxide) in the digestion apparatus (Kjeltec System HT 2, Foss tecator, Hoganäs, Sweden). The distillate, trapped into boric acid solution, was titrated with 0.1 M HCL using a mixture of methyl blue and methyl red as indicators to obtain total nitrogen. Crude protein was calculated using a correction factor of 6.25 .

\subsection{Determination of Crude Lipid}

Weighed cassava flour was extracted using petroleum ether in a Sohxlet extraction unit (Soxtec System, Hoganäs, Sweden), according to the method described by AOAC (1995).

\subsection{Determination of Starch}

Total starch content of the samples was estimated using the Anthrone reagent. The sample was first treated with 80:20 (v/v) ethanol/water to extract soluble sugars and the residual starch was hydrolysed with $52 \%$ perchloric acid into monosaccharide (glucose). The glucose was then dehydrated to hydroxymethyl furfural. This compound forms a green coloured product with anthrone. The sugar was colorimetrically determined with $95 \%$ phenol-sulphuric acid by means of a UV-VIS spectrometer (UV - 1601, Shimadzu, Japan) at $630 \mathrm{~nm}$. The total starch content was obtained by multiplying the glucose content obtained from the sample using the calibration graph by a factor of 0.9 provided. The calibration graph was prepared by diluting a standard glucose stock solution to obtain a concentration of glucose between 0.02 and $0.1 \mathrm{mg} / \mathrm{mL}$.

\subsection{Determination of the Minerals}

The amounts of $\mathrm{Ca}, \mathrm{Zn}, \mathrm{Fe}, \mathrm{Mg}$, and $\mathrm{Cu}$ in cassava was determined using Atomic Absorption Spectrophotometer (AAS) (AAS system, Analyst 400, 2009, Perkin Elmer, Singapore) as described by AOAC (1995). Weighed dry sample was ashed in a muffle furnace at $550{ }^{\circ} \mathrm{C}$ for $5 \mathrm{hrs}$. The ash was dissolved in $5 \mathrm{~mL}$ of $20 \% \mathrm{HCl}$. The solution was warmed to dissolve any un-dissolved particles in the residue, filtered through an acid washed filter paper, the filter paper was washed and the solution diluted to volume with potassium chloride solution. The mineral contents: Calcium (Ca), Zinc ( $\mathrm{Zn})$, Iron $(\mathrm{Fe})$, Magnesium $(\mathrm{Mg})$, and Copper $(\mathrm{Cu})$ were determined at the respective wavelengths $(\lambda)$ of 317.0, 213.9, 248.3, 285.2, and $324.8 \mathrm{~nm}$.

\subsection{Determination of Phytate}

The phytate content was determined using the anion-exchange method according to Ma et al. (2005). Cassava flour $(1.40 \mathrm{~g})$ was transferred into $100 \mathrm{~mL}$ conical flasks. A total of $40 \mathrm{~mL}$ of $\mathrm{Na}_{2} \mathrm{SO}_{4}(100 \mathrm{~g} / \mathrm{L})$ and $50 \mathrm{~mL}$ of 
$\mathrm{HCl}(1.2 \%)$ were added. Flasks were capped and shaken vigorously for $2 \mathrm{hr}$ on a rotator at ambient laboratory temperature. The above mixture was then centrifuged at $500 \mathrm{rpm}$ for $20 \mathrm{~min}$, after which the supernatant solution was filtered through qualitative filter paper No. 4 (Whatman, U.K.). A total of $10 \mathrm{~mL}$ of filtered extract was diluted to $30 \mathrm{~mL}$ with distilled water after mixing with $1 \mathrm{~mL}$ of $0.75 \mathrm{M} \mathrm{NaOH}$ and then passed through an anion resin column (resin, AG1-X4, 100-200 mesh, BioRad Laboratory, Inc., CA; column, $0.8 \times 10 \mathrm{~cm}$, Beijing Glass Instrumental Factory). The column was washed before use with $20 \mathrm{~mL}$ of $0.5 \mathrm{M} \mathrm{NaCl}$ solution and deionized water until no $\mathrm{Cl}^{-}$can be detected. The absence of $\mathrm{Cl}^{-}$was verified by titrating the wash water with neutral silver nitrate using potassium chromate as indicator. Silver chloride is quantitatively precipitated before red silver chromate is formed. After sample application, the column was washed with $15 \mathrm{~mL}$ of distilled water and $20 \mathrm{~mL}$ of $0.05 \mathrm{M} \mathrm{NaCl}$ in order to remove inorganic phosphate. The retained phytic acid (the eluate) from the resin was eluted with $0.7 \mathrm{M} \mathrm{NaCl}$ to $25 \mathrm{~mL}$. The post column reagent was made up as a $0.03 \% \mathrm{FeCl}_{3}$ solution containing $0.3 \%$ sulfosalicylic acid. A total of $4 \mathrm{~mL}$ of the reagent was added into $5 \mathrm{~mL}$ of collected eluate and then centrifuged at $3000 \mathrm{rpm}$ for $10 \mathrm{~min}$. The absorbance of the supernatant was measured at $500 \mathrm{~nm}$ using a spectrophotometer (UV-1601, Shimadzu, Japan). A calibration curve for the colorimetric method was obtained by using sodium phytate standards (P-8810 Sigma Co., USA). The Phytate content was calculated using the standard curve. The calibration curve was prepared by taking absorbance of standards with concentration of sodium phytate between 10.0 and $80.0 \mu \mathrm{g} / \mathrm{mL}$

\subsection{Determination of Tannin}

The tannin content was estimated using Folin - Denis method (Markkar, 1989; Markkar et al., 1993). This is based on the non-stoichiometric oxidation of the molecules containing a phenolic hydroxyl group. Tannin-like compounds reduce phosphotungstomolybdic acid in alkaine solution to produce ahighly coloured blue solution, the intensity of which is proportional to the amount of tannins. Absorbance was taken using spectrophotometer (UV-1601, Shimadzu, Japan) at $760 \mathrm{~nm}$ and concentration was estimated from the tannic acid standard curve and results were expressed as milligrams of tannic acid equivalents (TAE) per $100 \mathrm{~g}$ of dried sample. The calibration curve was prepared using tannic acid solution (Sigma-Aldrich, B0149-25G, Germany) with concentration range between 25 and $100 \mu \mathrm{g} / \mathrm{L}$.

\subsection{Determination of Oxalate}

Oxalate was determined by the method of Adeniyi et al. (2009). Two grams of cassava flour was digested with $10 \mathrm{~mL} 6 \mathrm{M} \mathrm{HCl}$ for $1 \mathrm{hr}$ and cooled. It was made to the mark in a $250 \mathrm{~mL}$ volumetric flask and filtered. $125 \mathrm{~mL}$ of the filtrate was measured into beakers and 4 drops of methyl red indicator was added. Concentrated $\mathrm{NH}_{4} \mathrm{OH}$ solution was added drop wise to the test solution until the colour changed from salmon pink to faint yellow and the $\mathrm{pH}$ of the solution was determined. Each portion was heated to $90{ }^{\circ} \mathrm{C}$ for $4 \mathrm{hr}$, cooled and then filtered to remove the precipitate. The filtrate was again heated to $90{ }^{\circ} \mathrm{C}$ and $10 \mathrm{~mL}$ of $5 \% \mathrm{CaCl}_{2}$ solution was added with continuous stirring. The solution was allowed to stand overnight and then decanted. The precipitate was completely dissolved in $10 \mathrm{~mL}$ of $20 \%$ (v/v) hot $\mathrm{H}_{2} \mathrm{SO}_{4}$ solution in water. The filtrate was made to $300 \mathrm{~mL}$ mark and aliquot of $125 \mathrm{~mL}$ of the filtrate was heated until near boiling, which was then titrated against standardized $(0.05 \mathrm{M})$ potassium tetraoxomanganate (VII) to give pink colour (which persists for $30 \mathrm{~s}$ ) at end point. Oxalate content was calculated as:

$$
\text { Oxalate content }(\mathrm{g} / 100 \mathrm{~g})=\frac{\mathrm{T} \times \mathrm{Vme} \times \mathrm{Df}}{\mathrm{MEx} \mathrm{MF}} * 100
$$

where : $\mathrm{T}$ is titre value of $\mathrm{KMnO}_{4} \mathrm{Vme}$ is volume-mass equivalent (that is, $1 \mathrm{ml}$ of $0.05 \mathrm{M} \mathrm{KMnO}_{4}=0.00228 \mathrm{~g}$ of anhydrous oxalic acid); $\mathrm{Df}$ is dilution factor; $\mathrm{Mf}$ is mass of sample; and $\mathrm{ME}$ is molar equivalent of $\mathrm{KMnO}_{4}$ in oxalate concentration $\left(\mathrm{g} / \mathrm{dm}^{3}\right)$.

\subsection{Determination of Cyanogenic Glycoside}

The alkaline pictrate method of Bradbury et al. (1999) was used in the determination of cyanogenic glucoside. Powdered cassava $(100.0 \mathrm{mg}$ ) was poured on top of a round paper disc containing phosphate buffer at $\mathrm{pH} 6$ and the enzyme linamarase in a flat-bottomed plastic bottle. Clean water $(0.5 \mathrm{~mL})$ was added to the sample, and immediately a yellow picrate paper attached to a plastic strip was added. The bottle was immediately closed with a screw capped lid. A blank was prepared the same way except that no sample was added. To verify the method, a standard linamarin paper was used. The bottle was allowed to stand for $24 \mathrm{hrs}$ at ambient temperature. The bottle was then opened and the colour of the picrate paper which developed was compared with the shades of the colour chart. The total cyanide content of the sample was read off from the colour chart. 


\subsection{Determination of total Carbohydrate}

The total carbohydrate content was determined by a difference method.

Total carbohydrate $=100-(\%$ moisture $+\%$ ash $+\%$ protein $+\%$ lipids $+\%$ fibre $)$

\section{Statistical data analysis}

Quantitative data was subjected to analysis using the IBM Statistical Package for Social Sciences (SPSS), version 23. Results are presented as Means \pm standard deviations. One way analysis of variance (ANOVA) was used to test for the difference among the varieties. Differences between means were considered significant at $\mathrm{p}<$ 0.05 .

\section{Results and Discussion}

\subsection{Proximate Composition}

Moisture contents differed significantly $(\mathrm{p}<0.05)$ among the cassava varieties except between NASE 3 and NASE 19 (Table 1). The moisture contents of the local cassava varieties were lower than those of the improved varieties (5.43\% for Nyamatia and $8.03 \%$ for Nyarukeca as compared to $10.07 \%$ for NASE 3, $8.65 \%$ for NASE 14, and $10.87 \%$ for NASE 19). Sarkiyayi and Agar (2010) reported much lower moisture values of $0.82 \%$ for sweet and $0.14 \%$ for bitter Nigerian cassava varieties. Baah, Oduro and Ellis (2005) reported moisture contents between 6.68 and $10.96 \%$ in peeled, washed, grated and de-watered cassava roots. Charles, Sriroth and Huang (2005) reported moisture contents between 9.2 and $12.3 \%$ among cassava varieties grown in Thailand. The differences in the moisture content may be due to their differences in textural structures and constituent solutes. The ash contents differed between the improved and local varieties. The improved cassava varieties had a higher level of ash (2.27\% for NASE 3 and NASE 19 and $2.39 \%$ for NASE 14) compared to the local varieties (1.5\% for Nyarukeca and $1.05 \%$ for Nyamatia), an indication of a higher mineral content in the improved varieties. Sarkiyayi et al. (2010) reported values of $2.71 \%$ for sweet and $1.85 \%$ for bitter cassava varieties. Safo-kantanka and Acquistucci (1996) reported ash contents between 1.2 and $1.6 \%$ among cassava varieties harvested at 13 months and between 1.2 and $2.1 \%$ among cassava varieties harvested at 6 months. Baah et al., (2005) reported ash contents between 1.15 and $1.2 \%$ in cassava varieties. Charles et al. (2005) reported ash contents between 1.3 and $2.8 \%$. In the present study all the investigated cassava varieties showed low fibre contents (approximately $1 \%$ ), which were not significantly different from each other except between NASE 19 and Nyamatia. Sarkiyay et al. (2010) reported fibre contents of $4.40 \%$ for sweet and $4.61 \%$ for bitter cassava varieties. Safo-kantanka et al. (1996) reported fibre contents of between 5.4 and $8.3 \%$ among cassava varieties harvested at 13 months; and between 3.9 and $6.1 \%$ among varieties harvested at 6 months. Baah et al. (2005) reported fibre contents between 2.9 and $3.64 \%$. Charles et al. (2005) reported higher fibre contents ranging from 1.5 to $3.5 \%$.

Table 1. Proximate composition (\%) of improved and local cassava varieties

\begin{tabular}{llllll}
\hline Parameters & NASE $^{\mathrm{S}}$ & ${\text { NASE } 14^{\mathrm{S}}}^{\mathrm{b}}$ & NASE19 $^{\mathrm{S}}$ & Nyamatia $^{B}$ & Nyarukeca $^{B}$ \\
\hline Moisture & $10.69 \pm 0.07^{\mathrm{a}}$ & $8.65 \pm 0.19^{\mathrm{b}}$ & $10.87 \pm 0.16^{\mathrm{a}}$ & $5.43 \pm 0.22^{\mathrm{c}}$ & $8.03 \pm 0.04^{\mathrm{d}}$ \\
Ash & $2.27 \pm 0.03^{\mathrm{a}}$ & $2.39 \pm 0.08^{\mathrm{a}}$ & $2.27 \pm 0.39^{\mathrm{a}}$ & $1.05 \pm 0.02^{\mathrm{b}}$ & $1.5 \pm 0.05^{\mathrm{b}}$ \\
Crude fibre & $1.08 \pm 0.03^{\mathrm{ab}}$ & $1.07 \pm 0.00^{\mathrm{ab}}$ & $1.18 \pm 0.03^{\mathrm{a}}$ & $1.06 \pm 0.02^{\mathrm{b}}$ & $1.08 \pm 0.01^{\mathrm{ab}}$ \\
Crude protein & $1.32 \pm 0.08^{\mathrm{a}}$ & $1.52 \pm 0.05^{\mathrm{a}}$ & $1.19 \pm 0.05^{\mathrm{a}}$ & $0.74 \pm 0.04^{\mathrm{b}}$ & $1.04 \pm 0.15^{\mathrm{c}}$ \\
Crude lipid & $0.48 \pm 0.05^{\mathrm{a}}$ & $0.57 \pm 0.01^{\mathrm{abd}}$ & $0.63 \pm 0.01^{\mathrm{b}}$ & $0.39 \pm 0.03^{\mathrm{acd}}$ & $0.48 \pm 0.01^{\mathrm{acd}}$ \\
Starch content & $84.42 \pm 1.98^{\mathrm{a}}$ & $75.25 \pm 1.40^{\mathrm{b}}$ & $66.72 \pm 3.65^{\mathrm{c}}$ & $78.44 \pm 2.22^{\mathrm{ab}}$ & $71.75 \pm 0.07^{\mathrm{bc}}$ \\
Total carbohydrate & $85.27 \pm 1.20^{\mathrm{bc}}$ & $85.83 \pm 0.43^{\mathrm{bc}}$ & $83.86 \pm 0.91^{\mathrm{c}}$ & $91.33 \pm 0.47^{\mathrm{a}}$ & $87.87 \pm 0.37^{\mathrm{b}}$ \\
\hline
\end{tabular}

Results are the averages of three determinations expressed on dry weight basis; S: Sweet variety, B: Bitter variety; Means within a row with different superscripts are significantly different at $p<0.05$.

Protein contents differed among the varieties except between NASE 3 and NASE 19, and between NASE 19 and Nyarukeca. The protein values were higher in the improved varieties (1.32 \% for NASE 3, $1.51 \%$ for NASE 14 , and $1.19 \%$ for NASE 19) compared to the local varieties (0.74\% for Nyamatia and $1.04 \%$ for Nyarukeca). Sarkiyayi et al. (2010) reported higher protein values (2.69\% for sweet and $3.37 \%$ for bitter varieties). Safo-kantanka et al. (1996) reported lower protein values of between $0.6 \%$ and $1.0 \%$ among six cassava varieties investigated. Baah et al. (2005) reported protein contents of 0.24 and $0.42 \%$. Charles et al. (2005) reported protein contents between 1.2 and $1.8 \%$. Nyakaisiki (2016) reported protein values between 0.5 and $1 \%$ on a fresh weight basis in some cassava varieties in western Uganda harvested at 12 months after planting. 
Differences in the protein content of cassava varieties may be due to genotype rather than environment. The study shows that cassava is not a major source of protein in the human diet.

Lipid contents were low in both improved $(0.48$ to $0.63 \%)$ and local $(0.39$ to $0.48 \%)$ varieties (Table 1$)$. Sarkiyayi et al. (2010) reported very high lipid values (3.92\% for sweet and $3.82 \%$ for bitter cassava varieties), while Safo-kantanka et al. (1996) reported lipid values of $1.5 \%$ and $2.2 \%$ for the cassava varieties. Charles et al. (2005) reported lower lipid contents of between 0.1 and $0.8 \%$ in cassava. Difference in lipid content of cassava varieties may be due to the genotype, since these varieties are grown in different countries on the African continent and in Thailand (Asia). In the Ugandan context, cassava is not a good source of lipid in the human diet.

Starch contents varied among the improved (84.42 \% for NASE 3, $75.25 \%$ for NASE 14 , and $66.72 \%$ for NASE 19) and between the local varieties (78.44\% for Nyamatia and $71.75 \%$ for Nyarukeca). Nuwamanya, Baguma, Emmambux, Taylor, and Rubaihayo (2010) reported starch contents ranging between 70.36 and $93.85 \%$ (dry basis) among local and improved cassava varieties grown in Uganda. Safo-kantanka et al. (1996) reported starch contents ranging from 69 to $71 \%$ in cassava roots from Ghana and Nigeria, while Baah et al. (2005) reported starch yields of $68.89 \%$ and $79 \%$ in cassava varieties in Ghana. Nyakaisiki (2016) reported starch contents ranging from 14 to $18 \%$ on fresh weight basis. According to the study, Ugandan cassava varieties are richer in starch than their counterparts in West Africa. Total carbohydrate content was between 83.86 and 91.33 , with significant difference between the local variety Nyamatia and all the other varieties both improved and local. Charles et al. (2005) reported a lower range of carbohydrates between 80.1 and $86.3 \%$. This makes Cassava an important source of carbohydrate in Uganda. Hence, variety but not environment or maturity of the roots may be of significance at the time of harvesting. However, Sarkiyayi et al. (2010) reported total carbohydrate content of $85.46 \%$ in sweet cassava varieties and $86.21 \%$ in bitter cassava varieties, showing a significant difference between the two varieties. This may mean that there is a difference in the potential of different varieties to accumulate carbohydrates in their cells.

Overall, the cassava varieties in this study conformed to the compositional requirements for cassava flour of the Uganda and East Africa Standards (crude ash content, max. $3.0 \%$; moisture content, max. $13 \%$; crude fibre content, max. $2.0 \%$; and acid insoluble ash, max. $0.35 \%$ and starch content b, min. 60\% ) (US 347: 2007; EAS 779:2012).

\subsection{Minerals}

Levels of minerals differed with cassava varieties (Table 2). Zinc, magnesium, copper, and calcium contents were particularly different in the varieties. The mineral contents were generally low except for calcium (13 to 18 $\mathrm{mg} / 100 \mathrm{~g}$ ), and magnesium (3.6 to $3.9 \mathrm{mg} / 100 \mathrm{~g}$ ). Sarkiyayi et al. (2010) reported higher values for calcium and for iron than levels in this study. Charles et al. (2005) reported much higher levels of calcium (136 to 369 $\mathrm{mg} / 100 \mathrm{~g}$ ) and for magnesium ( 31 to $43 \mathrm{mg} / 100 \mathrm{~g}$ ) in cassava varieties grown in Thailand. The copper contents in this study were between 0.002 and $0.14 \mathrm{mg} / 100 \mathrm{~g}$, which are within the limits required by the Ugandan Standards (US 235). Charles et al. (2005) reported higher levels of copper (between 0.037 and $0.057 \mathrm{mg} / 100 \mathrm{~g}$ ), zinc (between 13 and $19 \mathrm{mg} / 100 \mathrm{~g}$ ), and iron (between 29 and $40 \mathrm{mg} / 100 \mathrm{~g}$ ). Thai cassava varieties are thus richer in minerals than Ugandan varieties. Cassava roots may be a reasonable source of calcium and magnesium in the diet of Ugandans compared to other minerals evaluated.

Table 2. Levels of minerals of improved and local cassava varieties $(\mathrm{mg} / 100 \mathrm{~g})$

\begin{tabular}{lllcll}
\hline Element & NASE $^{\mathrm{S}}$ & ${\text { NASE } 14^{\mathrm{S}}}$ & ${\text { NASE } 19^{\mathrm{S}}}$ & Nyamatia $^{B}$ & Nyarukeca $^{B}$ \\
\hline Calcium & $16.56 \pm 1.19^{\mathrm{a}}$ & $14.28 \pm 0.02^{\mathrm{b}}$ & $14.88 \pm 0.01^{\mathrm{c}}$ & $13.15 \pm 0.03^{\mathrm{d}}$ & $18.09 \pm 0.01^{\mathrm{e}}$ \\
Iron & $0.01 \pm 0.00^{\mathrm{a}}$ & $0.01 \pm 0.00^{\mathrm{ab}}$ & $0.01 \pm 0.001^{\mathrm{a}}$ & $0.01 \pm 0.00^{\mathrm{ab}}$ & $0.01 \pm 0.00^{\mathrm{ab}}$ \\
Zinc & $0.87 \pm 0.00^{\mathrm{a}}$ & $0.64 \pm 0.00^{\mathrm{b}}$ & $0.64 \pm 0.003^{\mathrm{b}}$ & $0.56 \pm 0.00^{\mathrm{c}}$ & $0.60 \pm 0.00^{\mathrm{d}}$ \\
Magnesium & $3.73 \pm 0.00^{\mathrm{a}}$ & $3.67 \pm 0.01^{\mathrm{b}}$ & $3.58 \pm 0.000^{\mathrm{c}}$ & $3.65 \pm 0.00^{\mathrm{b}}$ & $3.88 \pm 0.01^{\mathrm{c}}$ \\
Copper & $0.14 \pm 0.00^{\mathrm{a}}$ & $0.05 \pm 0.01^{\mathrm{b}}$ & $0.08 \pm 0.00^{\mathrm{c}}$ & $0.002 \pm 0.00^{\mathrm{d}}$ & $0.03 \pm 0.00^{\mathrm{e}}$ \\
\hline
\end{tabular}

Results are the averages of three determinations expressed on dry weight basis; S: Sweet variety, B: Bitter variety; Means within a row with different superscripts are significantly different at $p<0.05$.

\subsection{Anti-Nutritional Compounds}

Levels of the cyanogenic glycosides were significantly higher in the local varieties compared to the improved varieties (Table 3). Sarkiyayi et al. (2010) reported much lower cyanogenic glucoside values of $4.6 \mathrm{mg} / \mathrm{kg}$ and $6.5 \mathrm{mg} / \mathrm{kg}$ for sweet and bitter cassava varieties respectively. Nyakaisiki (2016) reported cyanogenic glucoside contents ranging between 28 and $53 \mathrm{mg} / \mathrm{kg}$ on fresh weight basis. Charles et al. (2005) reported lower values for 
cyanide potential in cassava varieties from Thailand, ranging from 8.33 to $28.8 \mathrm{mg} / \mathrm{kg}$ on dry weight basis. The cyanide potential ranged between 26.9 and $28.8 \mathrm{mg} / \mathrm{kg}$ in bitter cassava varieties and between 8.33 and 12.5 $\mathrm{mg} / \mathrm{kg}$ in sweet cassava varieties. According to Uganda Standards, the total hydrocyanic acid content of cassava flour shall not exceed $10 \mathrm{mg} / \mathrm{kg}$ (US 347: 2007). The high data for cyanide obtained in this study may be due to the effect of interfering compounds (sulphite, sulphide, iodine, chloride and thiosulphate). The local varieties are also bitter, implying that the level of cyanogenic glucosides in a cassava root is directly related to bitterness. Since cyanogenic glucosides release the toxic cyanide as a breakdown product, bitterness of a cassava root is directly related to its toxicity.

Phytate contents were high for all cassava varieties and differed significantly. It was higher in improved varieties compared to local varieties (Table 3). Sarkiyayi et al. (2010) reported much higher phytate values of 2,160 $\mathrm{mg} / \mathrm{kg}$ and 3,040 mg/kg for sweet and bitter cassava varieties respectively. Charles et al. (2005) reported phytate levels ranging between 950 and $1,360 \mathrm{mg} / \mathrm{kg}$ in cassava with no difference between sweet and bitter varieties. Phytate may impair the bioavailability of iron, calcium, magnesium, and zinc in the diets of people dependent on cassava as a staple food. However, phytate may play the role of an antioxidant by sequestering iron and thus hinder the formation of free radicals.

Oxalate contents differed significantly among the cassava varieties in this study. The levels were generally higher in improved varieties compared to local varieties (Table 3). Sarkiyayi et al. (2010) reported oxalate contents of $220 \mathrm{mg} / \mathrm{kg}$ in sweet and $440 \mathrm{mg} / \mathrm{kg}$ in bitter cassava varieties. Oxalates may chelate minerals such as calcium, zinc and iron and therefore prevent their absorption and utilization by the human body.

Tannin contents differed among the cassava varieties studied except among NASE 14, NASE 19, and Nyamatia (Table 3). The tannin levels were generally higher in improved cassava varieties than in the local varieties. The levels in this study were lower than those reported by Sarkiyayi et al. (2010). In cassava, wound responses may lead to the formation of condensed tannins in the roots which cause a discolouration of the vascular tissue and storage parenchyma. The levels of the anti-nutrients in this study (cyanide, phytate, oxalate and tannin) may be significantly reduced by processing of cassava roots, such as cooking, fermentation and soaking, and hence render the processed roots safe for human consumption.

Table 3. Anti-nutritional composition of improved and local cassava varieties ( $\mathrm{mg} / \mathrm{kg})$

\begin{tabular}{llllll}
\hline Parameter & NASE $^{\mathrm{S}}$ & NASE14 $^{\mathrm{S}}$ & ${\text { NASE } 19^{\mathrm{S}}}^{\mathrm{d}}$ & Nyamatia $^{B}$ & Nyarukeca $^{B}$ \\
\hline Cyanogenic glucoside & $30.00 \pm 0.00^{\mathrm{d}}$ & $50.00 \pm 0.00^{\mathrm{c}}$ & $30.00 \pm 0.00^{\mathrm{d}}$ & $800.00 \pm 0.00^{\mathrm{a}}$ & $200.00 \pm 0.00^{\mathrm{b}}$ \\
Phytates & $984.64 \pm 0.00^{\mathrm{a}}$ & $959.57 \pm 0.80^{\mathrm{a}}$ & $877.14 \pm 19.60^{\mathrm{b}}$ & $773.92 \pm 8.04^{\mathrm{c}}$ & $661.33 \pm 20.23^{\mathrm{d}}$ \\
Oxalates & $227.80 \pm 4.05^{\mathrm{a}}$ & $181.60 \pm 0.11^{\mathrm{b}}$ & $161.40 \pm 2.02^{\mathrm{c}}$ & $140.40 \pm 1.21^{\mathrm{d}}$ & $90.60 \pm 0.21^{\mathrm{e}}$ \\
Tannins & $0.325 \pm 0.01^{\mathrm{a}}$ & $0.29 \pm 0.04^{\mathrm{b}}$ & $0.26 \pm 0.02^{\mathrm{b}}$ & $0.24 \pm 0.03^{\mathrm{b}}$ & $0.18 \pm 0.00^{\mathrm{c}}$ \\
\hline
\end{tabular}

Results are the averages of three determinations expressed on dry weight basis; S: Sweet variety, B: Bitter variety; Means within a row with different superscripts are significantly different at $p<0.05$.

\section{Conclusions}

The proximate composition, mineral composition, and contents of anti-nutritional factors in cassava differ between improved and local varieties. The improved varieties are generally sweet while the local varieties are bitter. The protein contents are within the range required by some industries utilizing cassava flour in their processes. The cyanogenic contents of all the cassava varieties studied are above the value stipulated in the Uganda Standards for cassava flour making them unsuitable for use in their primary form. The generally low mineral contents will necessitate the fortification of the flour used for production of human food. The high starch contents of the cassava varieties in this study make the cassava roots valuable raw materials for industrial utilization.

\section{Acknowledgements}

Sincere thanks go to the Staff Development Program of Kyambogo University (Uganda) which provided facilitation with a grant from the University's Research Fund and secondly, Picrate Kit for cyanide detection (Protocol B2) which was donated by Howard Bradbury, Australian National University.

\section{References}

Aalbersberg, W. G. L., \& Limalevu, L. (1991). Cyanide contents in fresh and processed Figian cassava (Manihot esculenta) cultivars. Tropical Science, 31, 249-256.

Adeniyi, S. A., Orjiekwe, C. L., \& Ehiagbonare, J. E. (2009). Determination of alkaloids and oxalates in some 
selected food samples in Nigeria. African Journal of Biotechnology, 8(1), 110-112.

Afoakwa, E. O., Budu, A. S., Asiedu, C., Chiwona-Karltun, L., \& Nyirenda, D. B. (2011). Application of Multivariate Techniques for Chsaracterizing Composition of starches and Sugars in Six High Yielding CMD Resistant Cassava (Manihot esculenta Crantz) Varieties. Journal of Nutrition \& Food Sciences, 1, 111. https://doi.org/10.4172/2155-9600.1000111

Ameny, M. A. (1990). Traditional Postharvest Technology of Cassava in Uganda. Tropical Science, 30, 41-50.

Anyiro, C. O., \& Onyemachi, A. D. (2014). Adoption of Cassava Value added Innovation and its Implication on Rural Livelihood: A case of rural women in Abia State, Nigeria. The Ninth African Economic Conference on the theme "Knowledge and Innovation for Africa's Transformation". Addis Ababa, Ethiopia. Accessed at: https://www.researchgate.net/publication/296183628

AOAC (1995). Official Methods of Analysis. 16 ${ }^{\text {th }}$ edition. Association of Official Analytical Chemists. Washington D.C., USA.

Asiedu, J. J. (1989). Processing Tropical Crops. A Technological Approach. Macmillan Education Ltd., London, U.K., 1-23.

Baah, F. D., Oduro, I., \& Ellis, W. O. (2005). Evaluation of cassava and sweet potato flours for pasta production. Journal of science and technology, 25(1), 16-24.

Bokanga, E., Essers, A. J. A., Poulter, N., Rosling, H., \& Tewe, O. (eds) (1994). International Workshop on Cassava Safety. International Society for Horticultural Science, Wageningen, Netherlands. Acta Horticulturae 375.

Bokanga, M., Halkier, B., \& Moller, B. (1993). Studies on the biosynthesis of cyanogenic glucosides in cassava. Proceedings of the 1st Scientific Meeting of the Cassava Biotechnology Network (pp: 418-423). Cartegena, Colombia.

Bradbury, M. G., Egan, S. V., \& Bradbury, J. H. (1999). Determination of all forms of cyanogens in cassava roots and cassava products using picrate paper kits. Journal of the Science of Food and Agriculture, 79, 593-601. https://doi.org/10.1002/(SICI)1097-0010(19990315)79:4<593::AID-JSFA222>3.0.CO;2-2

Cardoso, A. P., Mirione, E., Ernesto, M., Massaza, F., Cliff, J., Haque, M. R., \& Bradbury, J. H. (2005). Processing of cassava roots to remove cyanogens. Journal of Food Composition and Analysis 18, 451-460. https://doi.org/10.1016/jfca.2004.04.002

Cassava: Adding Value for Africa (C:AVA). Accessed at: cava.nri.org/country/uganda.

Charles, A. L., Sriroth, K., \& Huang, T. C. (2005). Proximate Composition, Mineral Contents, Hydrogen Cyanide and Phytic Acid of 5 Cassava Genotypes. Food Chemistry, 92(4), 615-620. https://doi.org/10.1016/j.foodchem.2004.0.024

Corbishley, D. A., \& Miller, W. (1984). Tapioca, arrowroot, and sago starches: production. In: Whistler, R.L., J.N. BeMiller and E.F. Paschal (eds.). Starch: Chemistry and Technology. Second Edition. Academic Press, Inc, New York, N.Y., 469-478. https://doi.org/10.1016/B978-0-12-746270-7.50019-7

East African Standard: DEAS 779. (2012). High quality cassava flour-Specification. East African Community.

FAOSTAT (2011). Cassava Production Trends in Uganda. Accessed at: www.faostat.org

Graffham, A., Klei, U., Jagwe, J., Nabawanuka, J., Wanda, K., Kalunda, P., \& Ntibarikure, G. (2000). Industrial Markets for Starch-Based Products: An Assessment of the Industrial Potential of Cassava in Uganda. Accessed at: www.Foodnet.cgiar.org/market/Uganda

Ma, G., Jin, Y., Piao, J., Kok, F., Guusje, B., \& Jacobsen, E. (2005). Phytate, calcium, iron, and zinc contents and their molar ratios in foods commonly consumed in China. Journal of Agricultural and Food Chemistry, 53(26), 10285-10290. https://doi.org/10.1021/jf052051r

Markkar, H. P. S., Blommel, M., Borowy, N. K., \& Becker, K. (1993). Gravimetric Determination of Tannins and their correlation with chemical and protein precipitation methods. Journal of the Science of Food and Agriculture, 61, 161-165. https://doi.org/10.1002/jsfa.2740610205

Markkar, H. P. S. (1989). Protein precipitation methods for quantitation of tannins: a review. Journal of Agricultural and Food Chemistry, 37(4), 1197-1202. https://doi.org/10.1021/jf00088a083

Ndubueze-Ogaraku..E., \& Edema, O. I. (2015). Cassava Value Addition Chain Analysis in Ughelli North LocalGovernment area of Delta State, Nigeria. Nigeria Journal of Agriculture and environment, 11(1), 
23-28.

New Zealand Food safety Authority (NZFSA). Cyanogenic Glycosides - Information Sheet. Accessed at: www.foodsafet.govt.nz/elibrary/industry/Cyanogenic_Glycosides-Toxin.

Nuwamanya, E., Baguma, Y., Emmambux, N., Taylor, J., \& Rubaihayo, P. (2010). Physicochemical and functional characteristics of cassava starch in Ugandan varieties and their progenies. Journal of Plant Breeding and Crop Science, 2(1), 001-011

Nyakaisiki, E, (2016). Effectiveness of Pruning and High Relative Humidity Storage in Extending the Shelf life of Fresh Cassava Roots (unpublished Master's thesis). Kyambogo University, Uganda.

Safo-kantanka, O., \& Acquistucci, R. (1996). The physico-chemical properties of cassava starch in relation to the texture of the cooked root. Ghana Journal of Agricultural Science, 28/29, 69-80.

Sanni, L., Maziya-Dixon, B., Patino, M., Akoroda, M., Ezedinma, C., Okechukwu, R., Lemchi, J., Ogbe, F., Mukumbira, J., Ilona,P., Tarawali, G., Okoro, E., \& Dixon, A. (2005). Value addition to cassava in Africa: Challenges and Opportunities. African Crop Science Conference Proceedings, 7, 583-590.

Sarkiyayi, S., \& Agar, T. M. (2010). Comparative Analysis on the Nutritional and Anti-Nutritional Contents of the Sweet and Bitter Cassava Varieties. Advance Journal of Food Science and Technology, 2(6), 328-334.

Splittstoesser, W. E., \& Tunya, G. O. (1992). Crop Physiology of Cassava. Horticultural Reviews, 13, 105-120. https://doi.org/10.1002/9780470650509.ch3

The National Cassava Policy (NCP). (2013). Uganda Investment Authority, Ministry of Agriculture Animal Industry and Fisheries.

Uganda Census of Agriculture (UCA) (2008/2009). Vol. IV: Crop Area and Production Report. Uganda Bureau of Statistics (2010), pp 59.

Uganda Standard: US 347: (2007). Cassava flour - Specification. Uganda National Bureau of Standards.

Wheatley, C. C., Orrego, J. I., Sanchez, T., \& Granados, E. (1993). Quality evaluation of cassava core collection at CIAT. In: Roca, W.M. and Thro, A.M. (eds.). Proceedings of the first International Scientific Meeting of the Cassava Biotechnology Network, CIAT, Cartagena, Columbia, 255-264.

\section{Copyrights}

Copyright for this article is retained by the author(s), with first publication rights granted to the journal.

This is an open-access article distributed under the terms and conditions of the Creative Commons Attribution license (http://creativecommons.org/licenses/by/4.0/). 